\title{
GROWTH HABIT IN MINI TOMATO HYBRIDS FROM A DWARF LINE
}

\author{
HERANÇA DO HÁBITO DE CRESCIMENTO DE HÍBRIDOS DE MINITOMATE \\ OBTIDOS POR UMA LINHAGEM ANÃ
}

\author{
Rafael Resende FINZI'; Gabriel Mascarenhas MACIEL²; José Magno Queiroz LUZ ${ }^{3}$; \\ Andressa Alves CLEMENTE ${ }^{4}$; Ana Carolina Silva SIQUIEROLI ${ }^{2}$ \\ 1. Mestrando do Programa de Pós-Graduação em Agronomia, Universidade Federal de Uberlândia - UFU, Uberlândia, MG, \\ Brasil. rafaelfinzi@ hotmail.com; 2. Professor, Doutor, Universidade Federal de Uberlândia - UFU, Monte Carmelo, MG, Brasil; \\ 3. Professor, Doutor, Universidade Federal de Uberlândia - UFU, Uberlândia, MG, Brasil; 4. Graduanda em Agronomia - UFU, Monte \\ Carmelo, MG, Brasil.
}

\begin{abstract}
The growth habit directly influences the tomato architecture, impacting on agronomic performance of mini-tomato hybrids. However, little is known about the growth habit of mini-tomatoes hybrids obtained by the crossing of dwarf lines versus normal lines with different growth habits. The objective of this study was to determine the type of growth that occurs when crossing a mini-tomato dwarf line versus normal phenotype lines with indeterminate, determined and semi-determinate growth habit. The methodology consisted of biparental crosses [determined from a cross between a dwarf line with normal lines of different growth habits (determinate, semi-determinate and indeterminate)] and reciprocal backcrosses of the $\mathrm{F} 1$ to the parents [normal lines $\left(\mathrm{P}_{1}\right)$ and dwarf line $\left(\mathrm{P}_{2}\right)$ ], and obtained the F2 generation. Was evaluated phenotypically the growth habit in each generation. The growth habit proportions of $\mathrm{F}_{1}\left(\mathrm{P}_{1} \mathrm{xP}_{2}\right), \mathrm{F} 1\left(\mathrm{P}_{2} \mathrm{x} \mathrm{P}_{1}\right), \mathrm{F}_{2}, \mathrm{~F}_{1} \mathrm{RC}_{1}\left(\mathrm{P}_{1}\right)$ and $\mathrm{F}_{1} \mathrm{RC}_{1}\left(\mathrm{P}_{2}\right)$, were classified after checking the expected and observed frequencies using the $\chi^{2}$ test $(\mathrm{F}=0.05)$. Was concluded that, when the determined and semi-determined growth habits are used as parents to produce hybrids, in $\mathrm{F}_{2}$ population growth habits shows 3:1 type segregation. Futhermore, regardless of the normal parent growth habit, the hybrids $\left(\mathrm{F}_{1}\right)$ always will show indeterminate growth when they are crossed with the mini-tomato dwarf line of this study.
\end{abstract}

KEYWORDS: Brix. Dwarfism. Mutation. Solanum lycopersicum.

\section{INTRODUCTION}

The tomato (Solanum lycopersicum L.) is one of the vegetables most economically important in the world. Among the types of tomatoes, minitomatoes stand out from the rest because of their smaller fruit and sweeter taste. Moreover, this type of tomato is distinguished by the higher margins it commands in the market (ABRAHÃO et al., 2014; MACIEL et al., 2016), encouraging growers and seed companies to invest in the vegetable. In this context, breeding programs have sought to develop new technologies, such as several formats and minitomato colors fruits, as well as hybrids with different growth habits.

The tomato has three growth habits: indeterminate, determined and semi-determinate, being this trait governed by genes of self-pruning family (PIOTTO; PERES, 2012). Compared to genotypes with indeterminate growth, in determinate growth is not necessary the accomplishment of onerous cultural practices such as sprout thinning, apical pruning and the conduct of plants with polythene strips or stakes (FILGUEIRA, 2008). However, the prioritization of the reproductive development among the vegetative can lead to a reduction in productivity and soluble solids content of the fruits in determinate genotypes (FRIDMAN et al., 2002). In contrast, semideterminate growth has an ideal balance between vegetative and reproductive development, having high productivity and high content of soluble solids in the fruits (VICENTE et al., 2015).

In addition to growth habit, genes that influence dwarf plants also could to be relevant in the development of mini-tomato hybrids. As well as small changes in self-pruning family genes can alter the tomato architecture (KRIEGER et al., 2010; VICENTE et al., 2015), the same could happen with the genes of dwarfism. The knowledge of the tomato architecture directly influences the agronomic performance and determines which are cropping practices will be adopted.

In this context, an inheritance study is necessary to determine the growth habit that can occur when the hybrids are obtained by the crossing of dwarf lines versus normal lines with different growth habits. The inheritance study of the growth habit can to determine the criterion and the intensity of selection progenies in breeding programs, conduction method of segregating populations, and number and interaction of genes involved (BUENO et al., 2006). 
The objective of this study was to determine the type of growth that occurs when crossing a minitomato dwarf line versus normal phenotype lines with indeterminate, determined and semideterminate growth habit.

\section{MATERIAL AND METHODS}

The experiment were conducted from November, 2015 to May, 2016 at the Estação Experimental de Hortaliças at the Federal University of Uberlandia (UFU) - Monte Carmelo Campus,

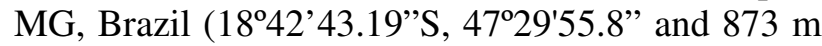
above sea level). The genetic material consisted of four mini-tomato lines with grape fruits (UFU1241E, UFU-42G, 451G and UFU-UFU-72152F), all belonging to the Bank of Germplasm Breeding Program Tomato-UFU. The UFU-1241E, UFU$42 \mathrm{G}$, and UFU-451G genotypes are characterized by a normal phenotype with determined, semideterminate and indeterminate growth habit, respectively. The UFU-72152F genotype is characterized by presenting atypical phenotype, having dwarf size and indeterminate growth (MACIEL et al., 2015b).

The methodology consisted of biparental crosses [determined from a cross between a dwarf line with normal lines of different growth habits (determinate, semi-determinate and indeterminate)] and reciprocal backcrosses of the F1 to the parents (normal lines and dwarf line), and obtained the F2 generation. All of the operations carried out in the biparental and reciprocal crosses, such as emasculation, pollen collection, pollination and plant identification, followed the methodology performed by Maciel et al. (2015b).

The plants were grown in the field, in the spacing of $0.5 \times 1.0 \mathrm{~m}$. The number of plants evaluated in each generation is described in Table 1. All cultural and phytosanitary treatments were performed in accordance with the recommendations for the tomato crop (ALVARENGA, 2013).

The characterization of tomato growth habit was given by the ratio between the number of leaves and inflorescences formed in each simpodial unit. Genotypes with three leaves and one inflorescence formed in each simpodial unit were classified as having the indeterminate growth habit (I); genotypes with two leaves and one inflorescence formed in each simpodial unit, with interruption of vegetative development in the main shoot to the formation of two consecutive inflorescences, were classified as having the semi-determinate growth habit (SD); and genotypes with three leaves and one inflorescence formed in the first simpodial unit, with gradual reduction of the number of leaves in subsequent units as well as interruption of vegetative development in the main shoot to the formation of two consecutive inflorescences, were classified as having the determined growth habit (D ) (FRIDMAN et al., 2002).

The growth habit proportions of $\mathrm{F}_{1}\left(\mathrm{P}_{1} \times \mathrm{P}_{2}\right)$, $\mathrm{F} 1\left(\mathrm{P}_{2} \mathrm{XP}_{1}\right), \mathrm{F}_{2}, \mathrm{~F}_{1} \mathrm{RC}_{1}\left(\mathrm{P}_{1}\right)$ and $\mathrm{F}_{1} \mathrm{RC}_{1}\left(\mathrm{P}_{2}\right)$, were classified after checking the expected and observed frequencies using the $\chi^{2}$ test $(\mathrm{F}=0.05)$. Statistical analysis of $\chi^{2}$ test was performed using the program Genes (CRUZ, 2013).

\section{RESULTS AND DISCUSSION}

When the determined and semi-determined growth habits are used as parents to produce hybrids, in $F_{2}$ population growth habits shows 3:1 type segregation, indicating that inheritance is controlled by a gene with two alleles, with one allele dominant over the other. This genetic hypothesis is confirmed by the results of both backcrosses in which only one gene with two alleles was involved (Tables 1 and 2). In a review done by Piotto and Peres (2012), the indeterminate growth habit character was demonstrably assigned by a dominant allele Self-Pruning (SP). It is noteworthy that the dwarf line UFU-72152F carrier the dominant allele SP and, regardless of the growth habit of the parents (determinate, semi-determinate and indeterminate), the hybrid will carry only the indeterminate growth habit.

In this way, in generation $F_{1} 100 \%$ of the hybrids showed the indeterminate growth habit, regardless of the growth habit of the UFU-1241E, UFU-42G and 451G UFU lines when combined with the dwarf line UFU-72152F (Table 1). These results corroborate and add to those of Maciel et al. (2015b) who conducted the inheritance test only for the indeterminate growth habit.

The knowledge of the growth habit in minitomato hybrids from dwarf lines is essential for growers and seed companies, because the growth habit reflects directly the phenological stage of the crop and can influence the productivity and the soluble solids of the mini-tomato fruits (MACIEL et al., 2015a; VINCENT et al., 2015; MACIEL et al., 2016). Although that $100 \%$ of the hybrids obtained by dwarf line UFU-72152F have presented indeterminate growth habit, one of the main advantages of the incorporation of dwarfing genes in the mini-tomato is the presence of shorter internodes, which confer more compact plants (GARDNER; PANTHEE, 2012; PANTHEE; GARDNER, 2013a,b). The compaction of tomato 
to facilitate the pruning practices and staking

Table 1. Numbers of plants evaluated and respective growth habits (determinate, semi-determinate and indeterminate) based on the UFU-72152F line (homozygous line for the indeterminate growth habit).

\begin{tabular}{|c|c|c|c|c|c|c|c|}
\hline \multirow{3}{*}{ Phenotypes } & \multicolumn{5}{|c|}{ Determinate growth habit $(\mathrm{D})$} & & \\
\hline & \multicolumn{3}{|c|}{ Selfings } & \multicolumn{2}{|c|}{ Reciprocal Crosses $\left(\mathrm{F}_{1}\right)$} & \multicolumn{2}{|c|}{ Backcrosses } \\
\hline & $\mathrm{P}_{1}$ & $\mathrm{P}_{2}$ & $\mathrm{~F}_{1}=\mathrm{F}_{2}$ & $\mathrm{~F}_{1}\left(\mathrm{P}_{1} \times \mathrm{P}_{2}\right)$ & $\mathrm{F}_{1}\left(\mathrm{P}_{2} \times \mathrm{P}_{1}\right)$ & $\mathrm{F}_{1} \times \mathrm{P}_{1}$ & $\mathrm{~F}_{1} \times \mathrm{P}_{2}$ \\
\hline $\mathrm{P}_{1}{ }^{(\mathrm{x})}=\mathrm{UFU}-1241 \mathrm{E}(\mathrm{D})^{(\mathrm{y})}$ & 40 & 0 & 16 & 0 & 0 & 19 & 0 \\
\hline $\mathrm{P}_{2}=\mathrm{UFU}-72152 \mathrm{~F}(\mathrm{I})$ & 0 & 38 & 45 & 43 & 39 & 17 & 34 \\
\hline Total & 40 & 38 & 61 & 43 & 39 & 36 & 34 \\
\hline \multicolumn{8}{|c|}{ Semi-determinate growth habit (SD) } \\
\hline \multirow{2}{*}{ Phenotypes } & \multicolumn{3}{|c|}{ Selfings } & \multicolumn{2}{|c|}{ Reciprocal Crosses $\left(\mathrm{F}_{1}\right)$} & \multicolumn{2}{|c|}{ Backcrosses } \\
\hline & $\mathrm{P}_{1}$ & $\mathrm{P}_{2}$ & $\mathrm{~F}_{1}=\mathrm{F}_{2}$ & $\mathrm{~F}_{1}\left(\mathrm{P}_{1} \times \mathrm{P}_{2}\right)$ & $\mathrm{F}_{1}\left(\mathrm{P}_{2} \times \mathrm{P}_{1}\right)$ & $\mathrm{F}_{1} \times \mathrm{P}_{1}$ & $\mathrm{~F}_{1} \times \mathrm{P}_{2}$ \\
\hline $\mathrm{P}_{3}=\mathrm{UFU}-42 \mathrm{G}(\mathrm{SD})$ & 40 & 0 & 14 & 0 & 0 & 22 & 0 \\
\hline $\mathrm{P}_{2}=\mathrm{UFU}-72152 \mathrm{~F}(\mathrm{I})$ & 0 & 42 & 43 & 36 & 28 & 18 & 25 \\
\hline Total & 40 & 42 & 57 & 36 & 28 & 40 & 25 \\
\hline \multirow{3}{*}{ Phenotypes } & \multicolumn{5}{|c|}{ Indeterminate growth habit (I) } & & \\
\hline & \multicolumn{3}{|c|}{ Selfings } & \multicolumn{2}{|c|}{ Reciprocal Crosses $\left(\mathrm{F}_{1}\right)$} & \multicolumn{2}{|c|}{ Backcrosses } \\
\hline & $\mathrm{P}_{1}$ & $\mathrm{P}_{2}$ & $\mathrm{~F}_{1}=\mathrm{F}_{2}$ & $\mathrm{~F}_{1}\left(\mathrm{P}_{1} \times \mathrm{P}_{2}\right)$ & $\mathrm{F}_{1}\left(\mathrm{P}_{2} \times \mathrm{P}_{1}\right)$ & $\mathrm{F}_{1} \times \mathrm{P}_{1}$ & $\mathrm{~F}_{1} \times \mathrm{P}_{2}$ \\
\hline $\mathrm{P}_{4}=\mathrm{UFU}-451 \mathrm{G}(\mathrm{I})$ & 40 & 0 & 46 & 29 & 24 & 35 & 26 \\
\hline $\mathrm{P}_{2}=\mathrm{UFU}-72152 \mathrm{~F}(\mathrm{I})$ & 0 & 23 & 0 & 0 & 0 & 0 & 0 \\
\hline Total & 40 & 23 & 46 & 29 & 24 & 35 & 26 \\
\hline
\end{tabular}

${ }^{(\mathrm{x})} \mathrm{P}_{1}=$ UFU-1241E: homozygous line for the determinate growth habit and normal size; $\mathrm{P}_{2}=$ UFU-72152F: homozygous line for the indeterminate growth habit and dwarf size; $\mathrm{P}_{3}=\mathrm{UFU}-42 \mathrm{G}$ : homozygous line for the semi-determinate growth habit and normal size; $\mathrm{P}_{4}=$ UFU-451G: homozygous line for the indeterminate growth habit and normal size; ${ }^{(y)} \mathrm{D}, \mathrm{SD}$ and I = determinate, semi-determinate and indeterminate phenotypes, respectively.

Table 2. $\chi^{2}$ test of the monogenic inheritance hypothesis for growth habits (determinate, semi-determinate and indeterminate) based on the UFU-72152F line (homozygous line for the indeterminate growth habit and dwarf size).

\begin{tabular}{|c|c|c|c|c|c|c|}
\hline \multirow{3}{*}{ Phenotypes } & \multicolumn{6}{|c|}{ Determinate growth habit (D) } \\
\hline & \multicolumn{3}{|c|}{$\mathrm{F}_{2}$ generation } & \multicolumn{3}{|c|}{ Backcrosses } \\
\hline & $\mathrm{OF}^{(\mathrm{w})}$ & $\mathrm{EF}$ & Deviation & OF & $\mathrm{EF}$ & Deviation \\
\hline $\mathrm{P}_{1}{ }^{(\mathrm{x})}=\mathrm{UFU}-1241 \mathrm{E}(\mathrm{D})^{(\mathrm{y})}$ & 16 & 15.25 & 0.75 & 19 & 18 & 1 \\
\hline $\mathrm{P}_{2}=\mathrm{UFU}-72152 \mathrm{~F}(\mathrm{I})$ & 45 & 45.75 & -0.75 & 17 & 18 & -1 \\
\hline Total & 61 & 61 & $\chi^{2}=0.0491$ & 36 & 36 & $\chi^{2}=0.1111$ \\
\hline
\end{tabular}

\begin{tabular}{|c|c|c|c|c|c|c|}
\hline \multirow{3}{*}{ Phenotypes } & \multicolumn{6}{|c|}{ Semi-determinate growth habit (SD) } \\
\hline & \multicolumn{3}{|c|}{$\mathrm{F}_{2}$ generation } & \multicolumn{3}{|c|}{ Backcrosses } \\
\hline & $\mathrm{OF}$ & $\mathrm{EF}$ & Deviation & $\mathrm{OF}$ & $\mathrm{EF}$ & Deviation \\
\hline $\mathrm{P}_{3}=\mathrm{UFU}-42 \mathrm{G}(\mathrm{SD})$ & 14 & 14.25 & -0.25 & 22 & 20 & 2 \\
\hline $\mathrm{P}_{2}=\mathrm{UFU}-72152 \mathrm{~F}(\mathrm{I})$ & 43 & 42.75 & 0.25 & 18 & 20 & -2 \\
\hline \multirow[t]{3}{*}{ Total } & 57 & 57 & $\chi^{2}=0.0058$ & 40 & 40 & $\chi^{2}=0.4$ \\
\hline & \multicolumn{6}{|c|}{ Indeterminate growth habit (I) } \\
\hline & \multicolumn{3}{|c|}{$\mathrm{F}_{2}$ generation } & \multicolumn{3}{|c|}{ Backcrosses } \\
\hline Phenotypes & $\mathrm{OF}$ & $\mathrm{EF}$ & Deviation & OF & EF & Deviation \\
\hline $\mathrm{P}_{4}=\mathrm{UFU}-451 \mathrm{G}(\mathrm{I})$ & 46 & 46 & 0 & 35 & 35 & 0 \\
\hline $\mathrm{P}_{2}=\mathrm{UFU}-72152 \mathrm{~F}(\mathrm{I})$ & 0 & 0 & 0 & 0 & 0 & 0 \\
\hline Total & 46 & 46 & $\chi^{2}=$ not applicable. & 36 & 36 & $\chi^{2}=$ not applicable \\
\hline
\end{tabular}


The indeterminate growth habit of the dwarf line UFU-72152F is the great differential of this work, because regardless of the growth habit of the parents (determinate, semi-determinate and indeterminate), the hybrid will carry only the indeterminate growth habit when they are crossed with the mini-tomato dwarf line of this study.

RESUMO: O hábito de crescimento influencia diretamente o desempenho agronômico de híbridos de minitomate. No entanto, pouco se sabe sobre o hábito de crescimento de híbridos de minitomate obtidos pelo cruzamento de linhagens anãs versus linhagens de fenótipos normais com diferentes hábitos de crescimento. O objetivo deste trabalho foi determinar o tipo de crescimento que ocorre entre o cruzamento de uma linhagem anã de minitomate versus linhagens de fenótipos normais com hábito de crescimento indeterminado, determinado e semi-determinado. A metodologia constou de cruzamentos biparentais recíprocos (determinados pelo cruzamento entre uma linhagem anã e linhagens normais com hábito de crescimento determinado, semi-determinado e indeterminado) e retrocruzamentos da geração F1 com os genitores [linhagens normais $\left(\mathrm{P}_{1}\right)$ e linhagem anã $\left(\mathrm{P}_{2}\right)$ ] e obtenção de geração $\mathrm{F} 2$. $\mathrm{O}$ hábito de crescimento foi avaliado fenotipicamente em cada geração. As proporções do hábito de crescimento em $\mathrm{F}_{1}\left(\mathrm{P}_{1} \mathrm{xP}_{2}\right), \mathrm{F} 1\left(\mathrm{P}_{2} \mathrm{XP}_{1}\right), \mathrm{F}_{2}, \mathrm{~F}_{1} \mathrm{RC}_{1}\left(\mathrm{P}_{1}\right)$ e $\mathrm{F}_{1} \mathrm{RC}_{1}\left(\mathrm{P}_{2}\right)$, foram realizadas após verificação das frequências observadas e esperadas, utilizando o teste $\chi^{2}(\mathrm{~F}=0,05)$. Foi concluído que, na obtenção de híbridos quando os genitores possuem hábito de crescimento determinado e semideterminado, na população $\mathrm{F}_{2}$ ocorre uma segregação do hábito de crescimento do tipo 3:1. Além disso, independentemente do hábito de crescimento dos parentais, os híbridos sempre irão possuir crescimento indeterminado quando forem obtidos pela linhagem anã de minitomate deste estudo.

PALAVRAS-CHAVE: Brix. Mutação. Nanismo. Solanum lycopersicum.

\section{REFERENCES}

ABRAHÃO, C.; BÔAS, R. L. V.; BULL, L. T. Relação K:Ca:Mg na solução nutritiva para a produção de minitomate cultivado em substrato. Irriga, Botucatu, v. 19, n. 2, p. 214-224, jun. 2014.

http://dx.doi.org/10.15809/irriga.2014v19n2p214

ALVARENGA, M. A. R. Tomate: produção em campo, em casa-de-vegetação e em hidroponia. Lavras: Editora UFLA, 2013. 455 p.

BUENO, L. C. S.; MENDES, A. N. G.; CARVALHO, S. P. Melhoramento Genético de Plantas: princípios e procedimentos. 2 ed. Lavras: Editora UFLA, 2006. 319 p.

CRUZ, C. D. GENES: a software package for analysis in experimental statistics and quantitative genetics. Acta Scientiarum, Maringá, v. 35, n. 3, p. 271-276, sept. 2013. http://dx.doi.org/10.4025/actasciagron.v35i3.21251

FIGUEIREDO, A. S. T.; MEERT, L.; PAULA, J. T.; RESENDE, J. T. V.; RODRIGUES, J. D.; ONO, E. O. Comportamento de plantas de tomateiro indeterminado na presença de regulador de crescimento. Revista Campo Digit@l, Campo Mourão, v. 10, n. 1, p. 31-40, ago. 2015.

FILGUEIRA, F. A. R. Novo manual de olericultura: Agrotecnologia moderna na produção e comercialização de hortaliças. Viçosa: Editora UFV, 2008. 421p.

FRIDMAN, E.; LIU, Y. S.; CARMEL-GOREN, L.; GUR, A.; SHORESH, M.; PLEBAN, T.; ESHED, Y.; ZAMIR, D. Two tightly linked QTLs modify tomato sugar content via different physiological pathways. Mol Genet Genomics, v. 266, n. 5, p. 821-826, jan. 2002. http://dx.doi.org/10.1007/s00438-001-0599-4

GARDNER, R. G.; PANTHEE, D. R. 'Mountain Magic': An Early Blight and Late Blight-resistant Specialty Type F1 Hybrid Tomato. Hortscience, v. 47, n. 2, p. 299-300, feb. 2012.

KRIEGER, U.; LIPPMAN, Z. B.; ZAMIR, D. The flowering gene SINGLE FLOWER TRUSS drives heterosis for yield in tomato. Nature Genetics, v. 42, n. 5, p. 459-463, may. 2010. http://dx.doi.org/10.1038/ng.550 
MACIEL, G. M.; FERNANDES, M. A. R.; MELO, O. D.; OLIVEIRA, C. S. Potencial agronômico de híbridos de minitomate com hábito de crescimento determinado e indeterminado. Horticultura Brasileira, Vitória da Conquista, v. 34, n. 1, p. 144-148, mar. 2016. http://dx.doi.org/10.1590/S0102-053620160000100022

MACIEL, G. M.; FERNANDES, M. A. R.; HILLEBRAND, V., AZEVEDO, B. N. R. Influência da época de colheita no teor de sólidos solúveis em frutos de minitomate. Scientia Plena, v. 11, n. 12, p. 1-6, nov. 2015a. http://dx.doi.org/10.14808/sci.plena.2015.120203

MACIEL, G. M.; SILVA, E. C.; FERNANDES, M. A. R. Ocorrência de nanismo em planta de tomateiro do tipo grape. Revista Caatinga, Mossoró, v. 28, n. 4, p. 259-264, dez. 2015b. http://dx.doi.org/10.1590/1983$21252015 \mathrm{v} 28 \mathrm{n} 429 \mathrm{rc}$

PANTHEE, D. R.; GARDNER, R. G. 'Mountain Honey' Hybrid Grape Tomato and Its Parent NC 6 Grape Breeding Line. Hortscience, v. 48, n. 9, p. 1192-1194, sept. 2013 a.

PANTHEE, D. R.; GARDNER, R. G. 'Mountain Vineyard' hybrid grape tomato and its parents: NC 4 Grape and NC 5 Grape tomato breeding lines. HortScience, v. 48, n. 9, p. 1189-1191, sept. 2013b.

PIOTTO, F. A.; PERES, L. E. P. Base genética do hábito de crescimento e florescimento em tomateiro e sua importância na agricultura. Ciência Rural, Santa Maria, v. 42, n. 11, p. 1941-1946, nov. 2012. http://dx.doi.org/10.1590/S0103-84782012001100006

VICENTE, M. H.; ZSÖGÖN, A.; TAL, L.; LOPO DE SÁ, A. F. L.; RIBEIRO, R. V.; PERES, E. P. Semideterminate growth habit adjusts the vegetative-to-reproductive balance and increases productivity and wateruse efficiency in tomato (Solanum lycopersicum). Journal of Plant Physiology, v. 177, p. 11-19, jan. 2015. http://dx.doi.org/10.1016/j.jplph.2015.01.003. 